\title{
Improvement in dietary intake estimates through the combined use of different approaches
}

\section{Melhora das estimativas de ingestão \\ dietética pela utilização conjunta \\ de duas abordagens}

\author{
Raíssa do Vale Cardoso LOPES1 (iD 0000-0003-0170-2875 \\ Juliana Araújo TEIXEIRA ${ }^{1}$ (D) 0000-0001-8155-1362

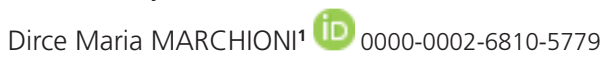 \\ Luisa Lina VILLA² (iD) 0000-0003-4074-2335

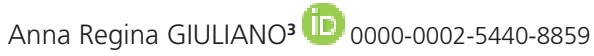 \\ Regina Mara FISBERG ${ }^{1}$ iD 0000-0002-4490-9035
}

A B S T R A C T

\section{Objective}

This study aimed to compare dietary intake estimates using two different methodological approaches: use of new portions obtained with the 24-Hour Diet Recall, which was applied in the current study population, and the application of calibration equations, which were estimated using the same $24 \mathrm{~h}$-recalls.

\section{Methods}

Calibration equations were estimated using linear regression. The medians and confidence intervals of energy and nutrient intakes were assessed using all the approaches. The U Mann Whitney test was applied to verify

\footnotetext{
1 Universidade de São Paulo, Faculdade de Saúde Pública, Departamento de Nutrição. Av. Dr. Arnaldo, 715, Cerqueira César, 01246-904, São Paulo, SP, Brasil. Correspondence to: RM FISBERG. E-mail: <rfisberg@usp.br>.

2 Universidade de São Paulo, Instituto do Câncer do Estado de São Paulo, Centro de Investigação Translacional em Oncologia. São Paulo, SP, Brasil.

${ }^{3}$ H. Lee Moffitt Cancer Center and Research Institute, Center for Immunization and Infection Research in Cancer. Tampa, Florida, United States.

Article based on the dissertation by RVC LOPES, entitled "Fatores dietéticos e persistência da infecção por HPV em homens". Universidade de São Paulo; 2015.
}

\section{How to cite this article}

Lopes RVC, Teixeira JA, Marchioni DM, Villa LL, Giuliano AR, Fisberg RM. Improvement in dietary intake estimates through the combined use of different approaches. Rev Nutr. 2019;32:e180137. http://dx.doi.org/10.1590/1678-98 65201932e180137 
differences among dietary intakes obtained with the 24 Hour Recall and Food Frequency Questionnaire-based methods. The correlation between different measures was assessed with Spearman coefficient. Weighted Kappa was used to verify the capability of the Food Frequency Questionnaire -based methods to classify individuals in the same intake levels of the 24 Hour Recall.

\section{Results}

Nine of the eleven components that were analyzed using the Food Frequency Questionnaire with standard portions and calibrated had medians significantly different from those obtained using the 24 Hour Recall; only the measurements of vitamin $\mathrm{E}$ and energy were statistically equal. For the Food Frequency Questionnaire with 24 Hour Recall portions, only the medians of vitamin $D$ and $B_{12}$ did not significantly differ from the 24 Hour Recall medians. Finally, for the Food Frequency Questionnaire with 24 Hour Recall portions and calibrated, all components, except folate and iron, had medians statistically equal to those obtained using the 24 Hour Recall. Spearman correlation coefficients were higher for the Food Frequency Questionnaire with 24 Hour Recall portions calibrated for all the assessed components, and the values ranged from 0.27 (total fat) to 0.57 (iron). Higher Kappa correlation coefficients were found for the Food Frequency Questionnaire 24 Hour Recall portions calibrated.

\section{Conclusion}

Calibrated FFQ with portions estimated from the own target population obtained better estimates of dietary intake, with values considerably more similar to those obtained with the reference method.

Keywords: Food consumption. Nutrition surveys. Statistical analysis.

\section{RE S U M O}

\section{Objetivo}

Comparar estimativas de ingestão alimentar de Questionário de Frequência Alimentar em conjunto a duas abordagens: porções obtidas de Recordatórios-24h aplicados na população de estudo, e equações de calibração, calculadas a partir dos mesmos Recordatórios-24h.

\section{Métodos}

Foram descritas medianas e intervalos de confiança de energia e nutrientes. O teste U de Mann-Whitney foi aplicado para verificar diferenças entre os dados obtidos com o Recordatório-24h e com o Questionário de Frequência Alimentar. A correlação entre as medianas de ingestão foi verificada com o coeficiente de correlação de Spearman; e para verificar se os métodos baseados no Questionário de Frequência Alimentar foram capazes de classificar os indivíduos nos mesmos níveis de ingestão do Recordatório-24h, foi utilizado o coeficiente de Kappa ponderado.

\section{Resultados}

Para o Questionário de Frequência Alimentar Porção Padrão calibrado, 9 dos 11 nutrientes analisados tiveram medianas diferentes das do Recordatório-24h. Para o Questionário de Frequência Alimentar Porção do Recordatório-24h, somente as vitaminas $D$ e $B_{12}$ não apresentaram diferença significativa em relação ao Recordatório-24h; para o Questionário de Frequência Alimentar Porção do Recordatório-24h calibrado, todos os nutrientes, à exceção de folato e ferro, tiveram medianas estatisticamente iguais às obtidas com o Recordatório24h. Os coeficientes de correlação de Spearman foram maiores para o Questionário de Frequência Alimentar Porção do Recordatório-24h calibrado para todos os nutrientes avaliados, variando de 0,27 (gordura total) a 0,57 (ferro). Em relação ao Kappa ponderado, os maiores coeficientes foram encontrados para o Questionário de Frequência Alimentar Porção do Recordatório-24h calibrado.

\section{Conclusão}

A utilização do Questionário de Frequência Alimentar calibrado e com porções estimadas na própria população de estudo apresenta melhores estimativas da ingestão alimentar, com valores mais próximos ao método de referência.

Palavras-chave: Consumo de Alimentos. Inquéritos Nutricionais. Análise Estatística.

\section{NTROD U CTION}

Food Frequency Questionnaires (FFQ) are commonly used for the assessment of usual dietary intake in epidemiological studies, particularly prospective studies, and it is considered an important 
tool for the investigation of the relationship between diet and the etiology, prevention, and treatment of diseases. Nevertheless, as all methods used in dietary intake assessment, it has measurement errors that affect risk and association estimates [1-9].

Considering that such errors are inherent to the method and aiming to minimize them, techniques have been developed to approximate the estimates of the FFQ to those of reference methods [2-9]. In addition to the instrument validation, calibration can also be used. This technique allows the adjustment of the food consumption measures of the FFQ based on measurements obtained using a reference method [10].

The FFQ used in the cohort study entitled "Natural History of HPV Infection In Men" (HIM study) in Brazil was developed by Fisberg et al. [11] based on the food intake of a representative sample of men in the city of São Paulo. In addition, validation [12] and calibration [10] studies were conducted, and the performance of the method was assessed when standard portions were replaced by portions obtained in a sub-sample of the Brazilian cohort [13], once portion determination is considered one of the main errors of dietary intake assessment $[14,15]$.

To obtain better dietary intake measurements, this study aimed to evaluate the performance of the FFQ when used in combination with other approaches: use of new portions obtained using the 24-Hour Recall (24HR), which was applied in the current study population, and the application of calibration equations, which were estimated using the same $24 \mathrm{H}$-recalls.

\section{METHODS}

\section{Study population}

The HIM study is a multinational prospective cohort that aims to determine the incidence, persistence, and remission of Human Papillomavirus (HPV) infection in men and to identify the factors associated with these outcomes among men from three different cities: Tampa (United States of America), Cuernavaca (Mexico), and São Paulo (Brazil). The detailed design of the HIM study is presented in a previous paper [16].

More than 4,000 men aged between 18 and 70 were included in the study from 2005 to 2009, and they were followed-up every 6 months for 4 years. In Brazil, the participants were recruited from the general population who visited the genitourinary clinic Centro de Treinamento DSTIAIDS, São Paulo (CRT-DST/AIDS, STD/AIDS Reference and Training Center) and from the general population of the Greater São Paulo via general media advertisements [17].

In this study, of the 1,412 participants in São Paulo, only 1,312 who had fully completed the FFQ were included in the analysis. The mean age of the participants was $34 \pm 10$ years.

\section{Dietary intake}

\section{Quantitative Food Frequency Questionnaire}

The Quantitative Food Frequency Questionnaire (QFFQ) used in the HIM study in Brazil was developed based on the dietary intake cited on the 24HR of 708 men in the population-based survey Inquéritos de Saúde de São Paulo (ISA-SP, Health Survey of São Paulo). The full description of the QFFQ development and validation is described in previous studies $[10,11]$. The participants in Brazil have reported the frequency of their consumption of the 54 food items (0-10 times a day, week, 
month, or year) over the past year and the size of the consumed portion (small, medium, large, and extra-large). To help participants in the visualization of the portion size, household measures were available during the interview. Dietary intake estimates were quantified using the Nutrition Data System for Research software version 2.0, 2007 (NDSR, University of Minnesota, Minneapolis, United States) and energy-adjusted using the residual method [18] with the purpose of estimating dietary intake regardless the energy consumption.

\section{4-Hour Dietary Recall}

A representative subsample $(n=121)$ of the Brazilian cohort answered to at least two $24 \mathrm{HR}$ in nonconsecutive days, which were applied by trained interviewers at the CRT-DST/AIDS using the Multiple Pass Method [19], which consists of a quick list of foods consumed in the previous day, a detailed description and the final revision.

To quantify dietary intake, the NDSR software was used. Nutrient distribution was adjusted for the within-person variation using the online software Multiple Source Method (MSM, German Institute of Human Nutrition, Potsdam-Rehbrücke, Germany), thereby obtaining the usual dietary intake. The residual method was applied to obtain energy-adjusted values [18].

To obtain the portions from the $24 \mathrm{HR}$, foods cited using this method were grouped according to the FFQ items and were divided into percentiles $(25,50,75$, and 95$)$ according to the number of individuals reporting their consumption in each of the $24 \mathrm{HR}$ applied that time. Weighting values were assigned, and the portions reported in all the $24 \mathrm{HR}$ were then attributed a higher weight. Finally, portions were multiplied by the total number of individuals who reported their consumption in each of the applied 24HR, as detailed by Carlos [13].

\section{Statistical Analysis}

Using the previously applied 24HR, it was possible to estimate the calibration equations of the dietary intake using linear regression. Adjusting variables, such as body mass index, income, education, age, ethnicity, marital status, physical activity, and smoking habits, were tested as adjustment in the models to minimize their potential effects on dietary intake report [20-22], and only those with models with a $p$ value $<0.20$ in the univariate linear regression analysis were selected.

The medians and confidence intervals were described for energy and nutrient intakes obtained using the four different methods: 24HR with de-attenuated and energy-adjusted intake estimates, which is considered the reference method; FFQ with standardized portions, energy-adjusted and calibrated intake estimates (calibrated FFQ SP); FFQ with standardized portions substituted by the portions obtained with the 24HR and energy-adjusted (FFQ 24HR); and FFQ with 24HR portions, energy-adjusted and calibrated (calibrated FFQ 24HR). The $U$ Mann-Whitney test was applied to verify significant differences among the medians of dietary intake obtained with the $24 \mathrm{HR}$ and FFQ-based methods.

The correlation between the medians of energy and nutrient intakes was verified with the Spearman correlation coefficient, and the weighted Kappa method was used to verify the performance of the FFQ-based methods in classifying individuals with the same intake levels as the $24 \mathrm{HR}$, comparing the tertiles obtained using each method. The weighting used is defined by the equation $1-\{(\mathrm{i}-\mathrm{j}) /(\mathrm{k}-1)\}^{\wedge} 2$, where $\mathrm{i}$ and $\mathrm{j}$ are the rows and columns of the two measurements, respectively, and $k$ is the total number of possible classifications. All analyses were performed using the Stata software version 12 (Stata Corporation, College Station, Texas, United States). 


\section{RES U L T S}

The medians of energy and nutrient intakes are presented in Tables 1 and 2 . For the calibrated FFQ SP, 9 of the 11 analyzed components were significantly different from the 24HR medians; only vitamin $E$ and energy had statistically equal medians. For the FFQ $24 \mathrm{HR}$, only vitamins $D$ and $B_{12}$ did not significantly differ from the $24 \mathrm{HR}$ medians. Finally, using the calibrated FFQ $24 \mathrm{HR}$, all the nutrients, except for folate and iron, had medians statistically equal to those obtained with the 24HR.

Table 1. Median and confidence interval $(95 \% \mathrm{Cl})$ of energy and nutrient intakes and correlation coefficients among the tested method (calibrated FFQ SP) and the reference method (24HR). São Paulo (SP), Brazil, 2015.

\begin{tabular}{|c|c|c|c|c|c|c|}
\hline \multirow{2}{*}{ Nutrient } & \multicolumn{2}{|c|}{$24 \mathrm{HR}^{\mathrm{a}}$} & \multicolumn{4}{|c|}{ Calibrated FFQ SPb } \\
\hline & Median & $(95 \% \mathrm{Cl})$ & Median & $(95 \% \mathrm{Cl})$ & Spearman & Kappa \\
\hline Energy (kcal) & 2396.10 & $(2280.0-2481.6)$ & 2417.3 & $(2400.5-2430.7)$ & $0.4413^{*}$ & 0.3158 \\
\hline Carbohydrates (g) & 294.50 & $(285.7-299.7)$ & 272.3 & $(271.8-272.4)^{*}$ & $0.3295^{*}$ & $0.2999^{*}$ \\
\hline Proteins (g) & 95.90 & $(93.6-98.8)$ & 94.4 & $(94.2-94.5)^{*}$ & $0.2989^{*}$ & $0.2013^{*}$ \\
\hline Total fat (g) & 89.10 & $(87.1-90.4)$ & 84.2 & $(83.9-84.3)^{*}$ & $0.2343^{*}$ & $0.1552^{*}$ \\
\hline Vitamin C (mg) & 84.70 & $(79.0-91.9)$ & 85.5 & $(84.3-86.6)^{*}$ & $0.4249^{*}$ & $0.3671^{*}$ \\
\hline Vitamin A (IU) & 6678.23 & $(6102.9-8008.0)$ & 8650.5 & $(8500.6-8780.1)^{*}$ & $0.4344^{*}$ & $0.3750^{*}$ \\
\hline Vitamin E (mg) & 7.20 & $(6.9-7.4)$ & 7.3 & $(7.27-7.32)$ & $0.2881^{*}$ & $0.3063^{*}$ \\
\hline Vitamin D (mcg) & 3.95 & $(3.59-4.16)$ & 3.4 & $(3.39-3.46)^{*}$ & $0.4099^{*}$ & $0.3501^{*}$ \\
\hline Vitamin $B_{12}(\mathrm{mg})$ & 5.90 & $(5.6-6.1)$ & 4.0 & $(3.97-4.03)^{*}$ & $0.3670^{*}$ & $0.3434^{*}$ \\
\hline Folate (DFE) & 723.50 & $(699.1-742.7)$ & 979.9 & $(974.6-986.5)^{*}$ & -0.0029 & -0.0112 \\
\hline Iron (mcg) & 17.80 & $(16.9-18.3)$ & 17.2 & $(17.2-17.3)^{*}$ & $0.4382^{*}$ & $0.3590^{*}$ \\
\hline
\end{tabular}

Note: ${ }^{*} p<0.05$. ${ }^{a}$ De-attenuated and energy-adjusted; ${ }^{\mathbf{b}_{\text {Energy-adjusted }}}$

24HR: 24-Hour Diet Recall; CI: Confidence Interval; DFE: mcg of Dietary Folate Equivalents; FFQ: Food Frequency Questionnaire; IU: International Units.

Table 2. Median and confidence interval $(95 \% \mathrm{CI})$ of energy and nutrient intakes and correlation coefficients among the tested methods (FFQ 24HR and calibrated FFQ 24HR) and the reference method (24HR). São Paulo (SP), Brazil, 2015.

\begin{tabular}{|c|c|c|c|c|c|c|c|c|}
\hline \multirow{2}{*}{ Nutrient } & \multicolumn{4}{|c|}{ FFQ 24HR ${ }^{a}$} & \multicolumn{4}{|c|}{ Calibrated FFQ 24HR } \\
\hline & Median & $(95 \% \mathrm{Cl})$ & Spearman & Kappa & Median & $(95 \% \mathrm{Cl})$ & Spearman & Kappa \\
\hline Energy (kcal) & 2749.8 & $(2,704.9-2,797.6)^{*}$ & $0.4603^{*}$ & $0.3202^{*}$ & 2448.8 & $(2,426.1-2,468.8)$ & $0.4746^{*}$ & $0.3636^{*}$ \\
\hline Carbohydrates (g) & 342.3 & $(339.9-346.5)^{*}$ & $0.3744^{*}$ & $0.2509^{*}$ & 294.7 & $(293.8-295.7)$ & $0.4350^{*}$ & $0.3541^{*}$ \\
\hline Proteins (g) & 111.0 & $(110.2-111.7)^{*}$ & $0.3222^{*}$ & $0.2318^{*}$ & 95.0 & $(94.8-95.2)$ & $0.3740^{*}$ & $0.3404^{*}$ \\
\hline Total fat (g) & 128.1 & $(127.3-128.9)^{*}$ & 0.1528 & $0.1615^{*}$ & 89.0 & $(88.8-89.2)$ & $0.2680^{*}$ & $0.2992^{*}$ \\
\hline Vitamin C (mg) & 126.4 & $(121.6-133.9)^{*}$ & $0.3526^{*}$ & $0.3978^{*}$ & 85.2 & $(83.7-86.5)$ & $0.4308^{*}$ & $0.3816^{*}$ \\
\hline Vitamin A (IU) & 9327.4 & $(9,040.5-9,568.2)^{*}$ & $0.3204^{*}$ & $0.3584^{*}$ & 6591.2 & $(6,516.4-6,683.9)$ & $0.4362^{*}$ & $0.4359^{*}$ \\
\hline Vitamin E (mg) & 8.1 & $(8.0-8.2)^{*}$ & $0.2632^{*}$ & $0.2754^{*}$ & 7.2 & $(7.2-7.3)$ & $0.3455^{*}$ & $0.3316^{*}$ \\
\hline Vitamin D (mcg) & 3.95 & $(3.88-4.04)$ & $0.4538^{*}$ & $0.3984^{*}$ & 3.65 & $(3.62-3.69)$ & $0.4594^{*}$ & $0.3764^{*}$ \\
\hline Vitamin $B_{12}(\mathrm{mg})$ & 6.1 & $(5.9-6.2)$ & $0.3494^{*}$ & $0.3304^{*}$ & 5.69 & $(5.66-5.72)$ & $0.3843^{*}$ & $0.3812^{*}$ \\
\hline Folate (DFE) & 605.7 & $(600.1-610.8)^{*}$ & $0.1929^{*}$ & $0.1617^{*}$ & 687.5 & $(683.2-691.7)^{*}$ & $0.4302^{*}$ & $0.4069^{*}$ \\
\hline Iron (mcg) & 18.5 & $(18.4-18.6)^{*}$ & $0.4931^{*}$ & $0.4149^{*}$ & 18.6 & $(18.5-18.7)^{*}$ & $0.5689^{*}$ & $0.4840^{*}$ \\
\hline
\end{tabular}

Note: * $p<0.05$. ${ }^{a}$ Energy-adjusted.

24HR: 24-Hour Diet Recall; CI: Confidence Interval; DFE: mcg of Dietary Folate Equivalents; FFQ: Food Frequency Questionnaire; IU: International Units. 
The Spearman correlation coefficients were higher for all the assessed components when using the calibrated FFQ 24HR, and the values ranged from 0.27 (total fat) to 0.57 (iron). Regarding the weighted Kappa coefficient, higher correlation coefficients were found for the calibrated FFQ 24HR; only vitamins C and D had higher coefficients using the non-calibrated FFQ 24HR (Table 2).

In addition to the $\mathrm{R}^{2}$ obtained using both calibrations (FFQ SP and FFQ 24HR), Figure 1 shows the distribution of energy, fat, vitamins $A$ and $E$, and iron intakes for all the four methods that were assessed. These nutrients were selected based on the lowest and highest obtained weighted Kappa coefficients using the calibrated FFQ 24HR.
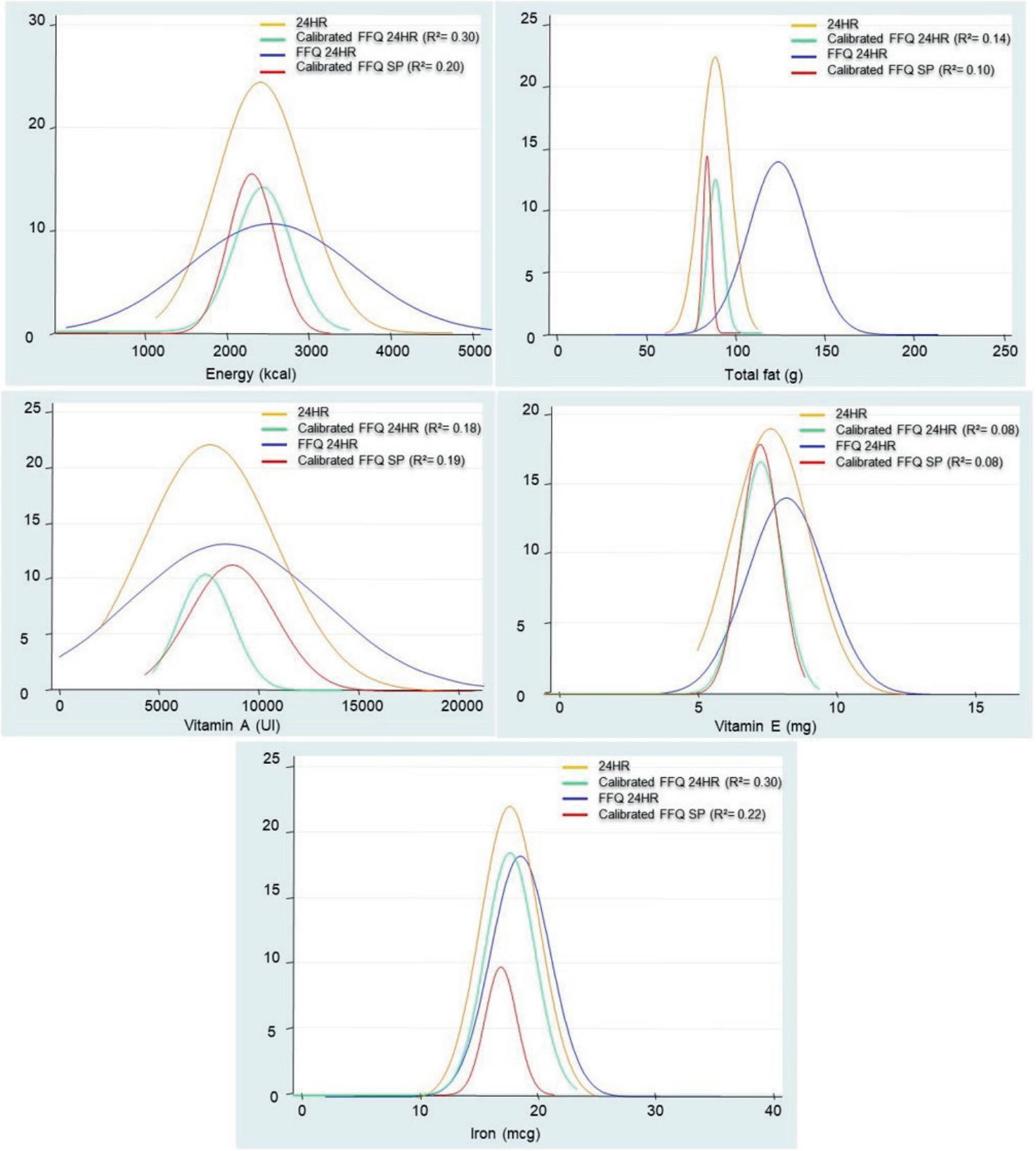

Figure 1. Distribution of energy and nutrient intakes according to the 24-HR, FFQ 24HR, calibrated FFQ SP and calibrated FFQ 24HR São Paulo (SP), Brazil, 2015. 


\section{DISCUSSION}

To the best of our knowledge, this is the first study to assess the performance of the validated FFQ used along with two other approaches: use of new portions obtained using data from the $24 \mathrm{HR}$, applied in the current study population, as an alternative to standard portions, and the application of calibration equations, which were calculated using the same $24 \mathrm{HR}$.

Our results indicate that the combined use of both approaches significantly improves the performance of the FFQ measures, making them more similar to the reference method than when used separately. Using standardized portions obtained from a population with different characteristics from the one in which the FFQ is applied may introduce a bias in dietary intake estimates $[14,15,23]$. Moreover, the calibration method provides food intake values more similar to the actual values $[10,24]$.

The medians of energy and nutrients of the calibrated FFQ 24HR were more similar to those of the reference method (24HR) than the other methods used for comparison. Similarly, Spearman correlation coefficients had higher values for the calibrated FFQ 24HR, and all components were significantly correlated to the pairs obtained with the reference method. In validation studies, correlation coefficients equal to or higher than 0.40 are considered acceptable [25-27]. In this study, the calibrated FFQ 24HR presented seven nutritional components with coefficients higher than 0.40, and only total fat had a value lower than 0.3 . Although considered a low coefficient, the use of the proposed approach (calibrated FFQ 24HR) increased the correlation with the reference method.

To assess the capacity of FFQ-based methods to classify individuals similarly to the reference method, data were distributed in tertiles, and weighted Kappa coefficient was used. A primary objective of FFQ in dietary assessment is to classify individuals according to intake levels, instead of absolute intake [28]. In our study, the weighted Kappa correlation coefficients indicated that the proposed method classified individuals satisfactorily in relation to the $24 \mathrm{HR}$; in general, such method had better coefficients than other FFQ-based methods. The improvement in the classification of individuals according to intake levels is also supported by the distribution graphics, where for the selected nutrients, the curve of the proposed method better approximates the curve of $24 \mathrm{HR}$ compared with other methods.

Regarding the calibration method, the $R^{2}$ values increased in 8 of the 11 assessed dietary components (data not shown) when calibration was applied to the FFQ 24HR. Once the $R^{2}$ value represents the explanatory power of the calibration model, our results indicate the improvement in calibration estimates when portions obtained with the $24 \mathrm{HR}$ were used instead of the standardized ones.

This study has limitations that must be presented. Although multiple $24 \mathrm{HR}$ are commonly used for FFQ validation and adjustment, they are not considered a gold standard method; therefore, even when considered as reference method, they are at risk for biases and inaccuracies. In addition, FFQ measures the usual diet in the previous year, while the multiple 24HR, even when used to obtain usual intake estimates, refer to a shorter period of time. If relevant modifications in diet occurs during this period, the concordance between these instruments decreases.

\section{CONCLUSION}

Our results indicate that the use of the calibrated FFQ with portions estimated in the current study population presents better estimates of dietary intake, with values considerably more similar to that obtained with the reference method. 


\section{CONTRIBUTORS}

RVC LOPES and RM FISBERG participated of the study conception and design, data analysis and interpretation. JA TEIXEIRA contributed with data analysis and interpretation. All authors participated of the review and approval of the final version of the manuscript.

\section{ACKNOWLEDGEMENTS}

We would like to thank Maria Luiza Baggio for helping in the collection of data used in this article, providing support during the review, and ensuring the consistency of the dietary data.

\section{REFERENCES}

1. Park Y, Dodd KW, Kipnis V, Thompson FE, Potischman N, Schoeller DA, et al. Comparison of self-reported dietary intakes from the Automated Self-Administered 24-h recall, 4-d food records, and food-frequency questionnaires against recovery biomarkers. Am J Clin Nutr. 2018;107(1):80-93.

2. Ocke MC, Mesquita HBB, Goddijn HE, Jansen A, Pols MA, van Staveren WA, et al. The Dutch EPIC food frequency questionnaire: I. Description of the questionnaire, and relative validity and reproducibility for food groups. Int J Epidemiol. 1997;26Supl1:S37-48.

3. Corrente JE, Marchioni DML, Fisberg RM. Validation of a FFQ (Food Frequency Questionnaire) for older people. J Life Sci. 2013;7(8):878-82.

4. Selem SSC, Carvalho AL, Verly-Junior E, Carlos JV, Teixeira JA, Marchioni DM, et al. Validity and reproducibility of a food frequency questionnaire for adults of São Paulo, Brazil. Rev Bras Epidemiol. 2014;17(4):852-9.

5. Willett WC, Sampson L, Stampfer MJ, Rosner B, Bain C, Witschi J, et al. Reproducibility and validity of a semiquantitative food frequency questionnaire. Am J Epidemiol. 1985;122:51-65.

6. Kroke A, Klipstein-Grobusch K, Voss S, Moseneder J, Thielecke F, Noack R, et al. Validation of a selfadministered food-frequency questionnaire administered in the European Prospective Investigation into Cancer and Nutrition (EPIC) Study: Comparison of energy, protein, and macronutrient intakes estimated with the doubly labeled water, urinary nitrogen, and repeated $24 \mathrm{~h}$ dietary recall methods. Am J Clin Nutr. 1999;70(4):439-47.

7. Avelino GF, Previdelli AN, Castro MA, Marchioni DM, Fisberg RM. Underreporting of energy intake and associated factors in a population-based study. Cad Saúde Pública. 2014;30(3):663-8.

8. Klipstein-Grobusch K, den Breeijen JH, Goldbohm RA, Geleijnse JM, Hofman A, Grobbee DE, et al. Dietary assessment in the elderly: Validation of a semiquantitative food frequency questionnaire. Eur J Clin Nutr. 1998;52:588-96.

9. Banna JC, McCrory MA, Fialkowski MK, Boushey C. Examining plausibility of self-reported energy intake data: Considerations for method selection. Front Nutr. 2017;4:45.

10. Teixeira JA, Baggio ML, Fisberg RM, Marchioni DML. Calibration of the dietary data obtained from the Brazilian Center of the Natural History of HPV Infection in Men study: The HIM study. Cad Saúde Pública. 2010;26(12):2323-33.

11. Fisberg RM, Colucci ACA, Morimoto JM, Marchioni DML. Questionário de freqüência alimentar para adultos com base em estudo populacional. Rev Saúde Pública. 2008;42(3):550-4.

12. Teixeira JA, Baggio ML, Giuliano AR, Fisberg RM, Marchioni DML. Performance of the Quantitative Food Frequency Questionnaire used in the Brazilian center of the prospective study Natural History of Human Papillomavirus Infection in Men: The HIM Study. J Am Diet Assoc. 2011;111(7):1045-51.

13. Carlos JV. Investigação da dieta habitual em estudo longitudinal sobre a infecção por HPV em homens. [Dissertação]. São Paulo: Universidade de São Paulo; 2011.

14. Welten DC, Carpenter RA, McPherson RS, Brodney S, Douglass D, Kampert JB, et al. Comparison of a dietary record using reported portion size versus standard portion size for assessing nutrient intake. Public Health Nutr. 1999;3(2):151-8. 
15. Køster-Rasmussen R, Siersma V, Halldorsson TI, Olivarius NF, Henriksen JE, Heitmann BL. Missing portion sizes in FFQ: Alternatives to use of standard portions. Public Health Nutr. 2014;18(11):1914-21. http://dx.doi. org/10.1017/S1368980014002389

16. Giuliano AR, Lazcano-Ponce E, Villa LL, Flores R, Salmeron J, Lee JH, et al. The human papillomavirus infection in men study: Human papillomavirus prevalence and typo distribution among men residing in Brazil, Mexico, and United States. Cancer Epidemiol Biomarkers Prev. 2008;17:2036-43.

17. Silva RJC, Sudenga SL, Sichero L, Baggio ML, Galan L, Cintra R, et al. HPV-related external genital lesions among men residing in Brazil. Braz J Infect Dis. 2017;21(4):376-85. http://dx.doi.org/10.1016/j.bjid.2017.03.004

18. Willett WC, Howe GR, Kushi LW. Adjustment for total energy intake in epidemiologic studies. Am J Clin Nutr 1997;65(4):1220S-8S.

19. Guenther PM, Cleveland LE, Ingwersen LA, Berline M. Questionnaire development and data collection procedures. In: Tippett KS, Cypel YS, editors. Design and operation: The continuing survey of food intakes by individuals and the Diet and Health Knowledge Survey, 1994-1996. Nationwide Food Surveys Report;96-1. Beltsville: United States Department of Agriculture; 1998. p.42-63.

20. Tooze JA, Subar AF, Thompson FE, Troiano R, Schatzkin A, Kipnis V. Psychosocial predictors of energy underreporting in a large doubly labeled water study. Am J Clin Nutr. 2004;79(5):795-804.

21. Hill RJ, Davies PS. The validity of self-reported energy intake as determined using the doubly labeled water technique. Br J Nutr. 2001;85:415-30.

22. Trabulsi J, Schoeller DA. Evaluation of dietary assessment instruments against doubly labeled water, a biomarker of habitual energy intake. Am J Physiol Endocrinol Metab. 2001;281:E891-9.

23. Pfrimer K, Sartorelli DS, Rosa FT, Resende CMM, Viera DVP, Rabito El, et al. Calibration of the food list and portion sizes of a food frequency questionnaire applied to free-living elderly people. Nutrition. 2013;29:760-4.

24. Ferrari P, Day NE, Boshuizen HC, Roddmam A, Hoffmann K, Thiébaut A, et al. The evaluation of the diet/ disease relation in the EPIC study: Considerations for the calibration and the disease models. Int J Epidemiol. 2008;37(2):368-78.

25. Subar AF, Kipnis V, Troiano RP, Midthune D, Schoeller DA, Bingham S, et al. Using intake biomarkers to evaluate the extent of dietary misreporting in a large sample of adults: The OPEN Study. Am J Epidemiol. 2003;158(1):1-13

26. Kipnis V, Subar AF, Midthune D, Freedman LS, Ballard-Barbash R, Troiano RP, et al. The structure of dietary measurement error: Results of the OPEN Biomarker Study. Am J Epidemiol. 2003;158(1):14-21.

27. Subar AF. Developing dietary assessment tools. J Am Diet Assoc. 2004;104(5):769-70.

28. Willett WC. Nutritional epidemiology. 3rd ed. New York: Oxford University Press; 2013. 